\title{
SOCIAL ENTREPRENEURSHIP INTENTION: A SYSTEMATIC LITERATURE REVIEW
}

\author{
Danang Nugroho*, Margo Purnomo, Bambang Hermanto, Erna Maulina \\ Department of Business Administration, University of Padjajaran, Bandung, Indonesia \\ *E-mail: danang17003@mail.unpad.ac.id \\ ORCID: 0000-0002-7189-5329
}

\begin{abstract}
The concept of Social Entrepreneurship is interesting because this research is focused on achieving profit but also creates benefits for the community, especially in the last decade. This study is to find out what is the impact of social entrepreneurial intention as a step to conduct a literature review to understand the new developments and discoveries that have emerged in previous research. The systematic literature review is used in this research methodology so that the systematically review can be explained. Based on the findings of the literature review study, it is expected that there are methods or frameworks that can be used for researchers as well as practitioners to understand the formation of social entrepreneurial intentions so that they can inspire further research.
\end{abstract}

\section{KEY WORDS}

Social entrepreneurial intention, social entrepreneur, systematic literature review, intentions.

Many research concepts from entrepreneurs are currently being studied by academics as one of the fields that have caught their attention in recent years. The concept of entrepreneurs is also glimpsed by the government because the impact of this entrepreneurial process is proven to be able to increase growth in the economic, social sector and also support political stability in a country. Research that supports this is from Thurik \& Wennekers, (2004) which states that the role of entrepreneurs can be an effective instrument to reduce social problems, then research from Nawaser et al, (2011) which states that there is a positive relationship between entrepreneurship and poverty reduction from Kebaili et al (2017).

The role of Entrepreneurship can be evidence in increasing effective instruments for economic value creation and can simultaneously solve various social problems. The concept which has two dual traits turns out to be increasingly popular in practice and theory, so that these two concepts have the name of a new research, namely "Social Entrepreneurship" (Nicholls, 2010). The concept of Social Entrepreneurship is needed for developing countries as one of the catalysts to accelerate the process of addressing gaps in social, economic and political development so that economic and social development can be an anticipate (Tiwari et al, 2017).

The concept of social entrepreneurs today uses a combination of principles that are used for companies, business principles, or principles commonly used by capitalism to be able to create social change by building or managing a business. This combination is done solely to address social problems with innovative solutions (Tran \& Korflesch, 2016). In addition to achieving profits, organizations in Social Entrepreneurship also prioritize other things in the form of benefits that can be felt by the wider community. This is what distinguishes Social Entrepreneurship from other entrepreneurial activities.

In this study, researchers will use analytics approach to find research that has been done on Social Entrepreneurial Intention. This analysis is conducted to learn how to apply the theory that has been used in the Social Entrepreneurs Intention. Basically, the purpose of this study is to discuss the Social Entrepreneurial Intention by discussing systematic literature, and offering some suggestions or references for related research in the future. The Systematic literature review method will provide information obtained from previous research, therefore research can provide advice based on research and empirical research. Furthermore, all of these articles will discuss the Concept Social Entrepreneurial Intentions, 
explanations about research, and the results of literature analysis, information obtained and suggestions for use based on theoretical perspectives.

\section{LITERATURE REVIEW}

The concept of social entrepreneurship dwells on idea about venture creations by adding social benefits as an end goal. Social entrepreneurs will always try various unique ways of providing solutions to various problems in education, environment, trade, health and human rights (Lacap et al, 2018). With this, social entrepreneurship is considered a key factor for a nation's sustainable development (Lacap et al., (2018); Mair \& Noboa, (2006)). Social entrepreneurship is considered a sub-discipline in the field of entrepreneurship. Mair \& Noboa, (2006) suggests that social entrepreneurship is a process that includes: discussing social problems and specific solutions (or solving solutions) to overcome them; evaluation of social impacts, business models and business sustainability, creating social mission for nonprofit business oriented that focus on dual or triple chases from the bottom line.

The environment of social entrepreneurship is based on the concept of business creation. The word "social" in social entrepreneurship explains art and science doing and creating opportunities and also organizations that require high creativity, risk taking and profit maximization. From the point of view of Jean-Baptiste Say as an economist, an entrepreneur is someone who uses resources to produce greater output and achieve high levels of productivity. As for Schumpeter (1975), an entrepreneur is an innovator. In addition, Drucker (1995) defines an entrepreneur as someone who continues to look for change and someone who uses opportunities in the environment (Lacap et al, 2018). From this perspective, Mair \& Martí, (2006) defines social entrepreneurship as an innovation process in which resources are used to take advantage of environmental opportunities and meet social needs. Therefore, social entrepreneurship is basically normal individuals who carry out extraordinary activities (Mair \& Noboa, 2006). This social entrepreneurship has an unyielding motivation to change society. This trait is known as entrepreneurial quality (Drayton, 2002).

The concept of social entrepreneurship is about helping others (Prabhu, 1999). The concept of social entrepreneurship can be altruism, in addition to helping other people, this activity can also fulfill the personal needs obtained when involved in these activities (Mair \& Martí, 2006). Even business companies, social entrepreneurship can be emphasized while looking for ways to achieve profitability. Therefore, while the main concern of entrepreneurs is to seek profit (Schumpeter, 1934; Baumol, (1993) there are several factors that motivate a venture creator engages itself in the field of entrepreneurship (Mair \& Martí, 2006).

There are several types of social entrepreneurship in Indonesia according to the DBS organization that take care of and monitor developments regarding the conditions of social entrepreneurship in Indonesia, for the first type is Community-based Social Enterprise, which is a business concept based on the community that has a concentration on the needs of the community itself , usually this activity is in the form of a trading union/cooperation called PERMASTE which was established to provide solutions to access special needs for the visually impaired community. In accordance with the empowerment orientation, each member and community will both get different benefits or profits (Haryanti et al, 2016).

The second type is Not-for-Profit Social Enterprise, which has the motivation from the establishment of social entrepreneurship, is a form of social concern as a way to overcome problems that occur in the community with a wider scope. For example here is a community called "BERBAGINASI" who try to raise rice packs or food from the community to be given to the homeless people, this community raises funds by selling various merchandise to public (Haryanti et al., 2016).

The third type is Hybrid Social Enterprise oriented business oriented to sustainable development. The condition of this business orientation requires a source of funds used to support a more diverse and balanced social business, from social, commercial, to commercial funds. One example is the Yayasan Cinta Anak Bangsa Foundation (YCAB) where targeted beneficiaries are underprivileged teenagers aged 10-24 years and underprivileged mothers. This foundation has consumers from the production of their 
products, besides that it also has a business unit in the form of individual donors, donor agencies or individuals / institutions that provide grants (Haryanti et al., 2016).

The fourth type is Profit-for Benefit Social Enterprise, which is a type of social entrepreneurship that is bigger than the three previous types because it has a vision and target in the form of fluency, development, and growth in forming organizations on a larger scale so that they can be independent without dependence on individuals or donors. An example of this type is Kampung Kearifan Indonesia enterprise (KKI) has activities in two parts, namely empowering local farmers to grow native Indonesian organic food and marketing their products in their own outlets which have the name The Ethno Gourmet Shop which has penetrated local and foreign markets (Haryanti et al., 2016).

Understanding an individual's goal of managing and building a business based on their's intentional behavior (Krueger \& Carsrud, 1993). According to Bird, (1988) entrepreneurial intention is a mental orientation that directs individuals towards conception and implementation of unique business concepts. This is an individual belief in establishing an organization and is determined to implement the plan to build a business in the future (Thompson, 2009). In the context of social entrepreneurship, social entrepreneurial intention is the belief and desire of an individual to establish a social organization (Tran \& Korflesch, 2016). So from this we can see that knowledge about social entrepreneurship is still very developed so that full study cannot be done yet. This study looks at the existence of several types in seeing the process from previous studies on Social Entrepreneurship.

\section{METHODS OF RESEARCH}

This study will be conducted using a systematic literature review. This method will help identify and make it easier for researchers to review previous research literature. This systematic literature review was adopted from Tranfield et al, (2003) which made it easier for researchers to conduct inclusion determinations according to the research theme and carry out exclusion processes that were not in accordance with the research recommendations. The use of this methodology will make it easier for researchers to get a comprehensive scope of literature. The methodology from Tranfield et al, (2003) uses 5 phases to facilitate the literature review process, namely planning, searching, screening, extraction, and synthesis, including reporting.

Planning. The researcher tried to make a plan in the study to be able to define the research question. The research question in this study is "What is the application of the formation of Social Entrepreneurial Intention?". The answers to the research questions will facilitate the content and see the theory and practice that occurs. The next step here is to identify the research database and use keystring for the search for the electronic database that is suitable for the research question.

Searching. The search process for related articles to this research question was carried out using 3 electronic databases: Emerald Insight, Sage pub and Proquest. The selection of this article is based on articles that provide good presentations about Entrepreneurial Intention, and related empirical research. The keywords used in this study is "Entrepreneurial Intention". Researchers use this keyword so they can see widely about Entrepreneurial Intention so they can answer research questions from general to specific.

Screening. The search results from these 3 electronic databases: Emerald Insight, Sage Pub, and Proquest produced 365 articles listed with the abstract. After that, the researcher reviews the results of the study using the research question, "What is the application of the formation of Social Entrepreneurial Intention?". Then the researchers carried out the specified inclusion and exclusion techniques to simplify the review of the articles. The inclusion criteria that the researchers did were:

- Only choose articles in English;

- Only articles in research papers;

- No Duplication;

- Read Abstract which contains an explanation the research question;

- Articles that show empirical research methods. 
And, the exclusion criteria that researchers do are:

- Articles not using English language;

- Not included articles others than research paper papers (such as magazines, books, conference papers, proceeding papers, audio / video, Thesis / dissertation);

- Articles that do not fit with the research question;

- Have duplication.

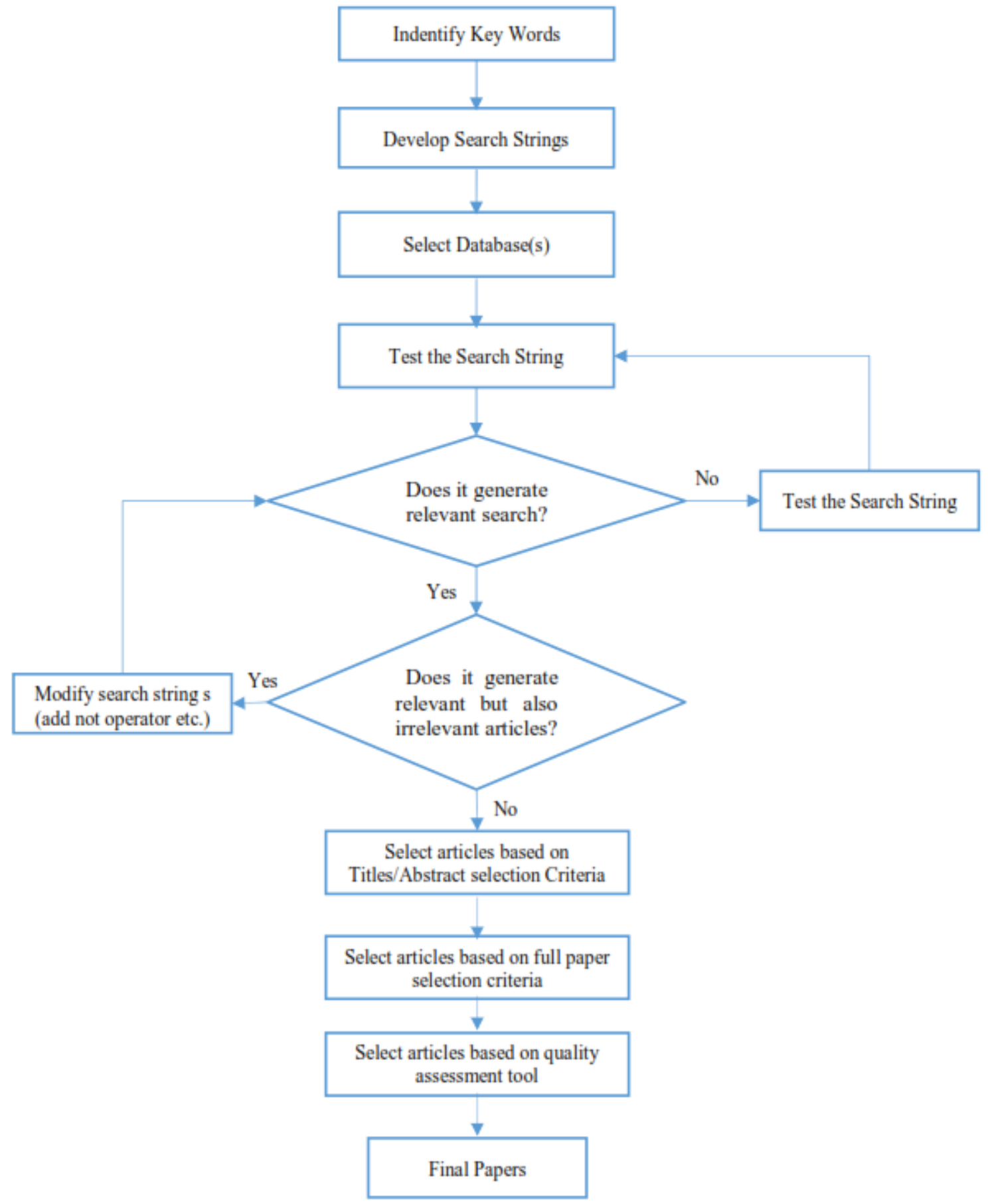

Figure 1 - Literature search process (Source: Chandorkar, 2013)

Extraction. Based on the results of the screening criteria above, the researcher obtained 57 articles from the inclusion results to search for "Entrepreneurial Intention" as a search technique in general, then the researchers' re-inclusion in accordance with research 
questions that only sought themes for Social Entrepreneurial Intention. So the researchers only got 6 articles that specifically answered the research questions. This shows that research on social entrepreneurial intention is still rarely done. Researchers deliberately chose these research keywords in general to see all of the methods and also theoretic basis used in research in general. From these results the researchers conducted in-depth reviews as outlined in Excel as the inclusion database. This database using Excel is useful to be able to find out and dissect the article in a structural dissection and reviews in the form of columns available in Excel (Tranfield et al, 2003). Using Excel column, researchers can group information on aspects of the article. Information that researchers do is by grouping articles in the form of Title, Author, Publisher, and year of publication. After doing this, the researcher also made a group for paper type, Research design, Research Method, and locus from the previous research. The next step, the main elements in making this article such as the purpose of research, definition of research, keywords used within the research, aspects, and analyzed units will be performed. The focus of this study is to look at the unit of analysis from previous studies on social entrepreneurial intention.

\section{RESULTS OF STUDY}

In this section, the researcher will explain the findings of a systematic review that has been identified based on group criteria in the excel database. The researcher will explain the findings of the article from the year and publication, namely as many as 6 previous articles that specifically discuss the research question.

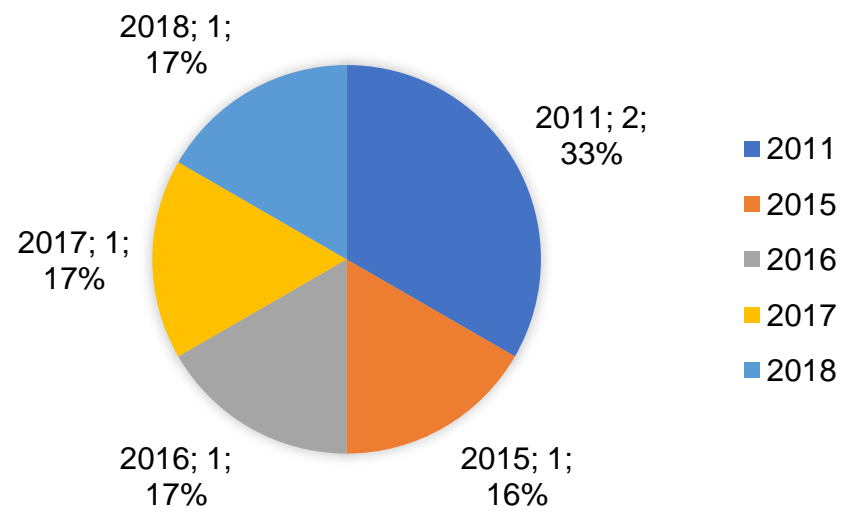

Figure 2 - Years of Articles Publications

Classification based on Year and Publication. The researchers found that the beginning of research on social entrepreneurial intention began in 2011. This shows that this research is still relatively fresh and able to improve new research about social entrepreneurial intention. From 6 articles that the researchers found, it was found 2 articles published in 2011 and the rest running every year from 2015-2018, each of which was 1 article. Publishers from these 6 articles are Asia Pacific Journal of Innovation and Entrepreneurship, South Asian Journal of Business Studies, Journal of Science and Technology Policy Management, Social Enterprise Journal, Education and Training, and finally the International Journal of Entrepreneurial Behavior \& Research.

Classification Based on paper type. Based on the classification of the systematic literature review, researchers classified the paper type from Petersen et al. (2008), there are 6 kinds of categories from the research paper facet:

1. Validation Research: These techniques investigated are novel and have not yet been implemented in practice. Techniques used are for example experiments, i.e., work done in the lab.

2. Evaluation Research: These techniques are implemented in practice and an evaluation of the technique is conducted. That means, it is shown how the 
technique is implemented in practice (solution implementation) and what are the consequences of the implementation in terms of benefits and drawbacks (implementation evaluation). This also includes identifying problems in industry.

3. Solution Proposal: A solution for a problem is proposed, the solution can be either novel or a significant extension of an existing technique. The potential benefits and the applicability of the solution is shown by a small example or a good line of argumentation.

4. Philosophical Papers: Papers sketch a new way of looking at existing things by structuring the field in form of a taxonomy or conceptual framework.

5. Opinion Papers: These papers express the personal opinion of somebody whether a certain technique is good or bad, or how things should been done. They do not rely on related work and research methodologies.

6. Experience Papers: Experience papers explain on what and how something has been done in practice. It has to be the personal experience of the author.

The findings from this previous study found that there are 2 results of articles from Tran \& Korflesch (2016) and Jiao (2011) using Philosophical Papers type, 2 previous studies using Validation Research, from Lacap et al (2018), Kirby \& Ibrahim (2011). And the next 2 studies using Evaluation Research, articles from Urban \& Kujinga (2017) and research from Hockerts (2015). There are still many opportunities to conduct this research in the social entrepreneurial intention field because this research is still very few.

Base on Know Theories, Tran \& Korflesch (2016) using the concept of "Entrepreneurial Event" model - Social Entrepreneurial Event, the theory of planned behavior - TPB from Ajzen (1991), the theory of planned behavior entrepreneurial model - TPBEM from Krueger \& Carsrud (1993), the social cognitive career theory (SCCT) from Lent et al, (1994) as the basis of conceptual models for case study research with the title "A conceptual model of social entrepreneurial intention based on the social cognitive career theory". Lacap et al, (2018) "The mediating effects of social entrepreneurial antecedents on prior experience and social entrepreneurial intentions" uses the concept of intentional behaviors from Krueger et al, (2000), the predictors of social entrepreneurial intentions Dari Hockerts, (2015), the antecedents of social entrepreneurial intentions Dari Mair \& Noboa, (2006) with research design research using PLS SEM. Jiao, (2011) "A conceptual model for social entrepreneurship directed toward social impact on society" research in the form of a conceptual model for entrepreneurs, using behavioral theory about desirability and feasibility of the social entrepreneur, human capital and social capital in the decision-making process. Kirby \& Ibrahim, (2011) "The case for (social) entrepreneurship education in Egyptian universities" using theoretical framework from Theory of Planned Behavior (Ajzen, 1991), Social entrepreneurship from Yunus, (2008), the concept of sizeable number expressed in interest in establishing a Social Enterprise from Seelos \& Mair, (2005) using SPSS and simple descriptive statistics in research design. Urban \& Kujinga, (2017) "The institutional environment and social entrepreneurship intentions" using concept model of entrepreneurial intentionality from Bird, (1988), theory of planned behavior (TPB) model from Ajzen, (1991) and the model of entrepreneurial events using research design covariance-based SEM with the CALIS program in SAS 9.3. And, the last one from Hockerts, (2015) "Determinants of Social Entrepreneurial Intentions" using theoretical framework antecedents of social entrepreneurial intentions from Mair \& Noboa, (2006), entrepreneurial intention theory from Krueger et al, (2000), and the theory of planned behavior dari Ajzen, (1991) using research design with SEM PLS.

The application of Social entrepreneurship intention, Hockerts, (2015) with the title "Determinants of Social Entrepreneurial Intentions" is a development of the Theory of Planned Behavior (Ajzen, 1991) which has been modified by Mair \& Noboa, (2006) it generate a new variable such as, Empathy, Moral Obligation, Social Entrepreneurial SelfEfficacy, Perceived Social Support and Experience as Antecedent of Social Entrepreneurial Intention. This study uses a survey method to 181 Malaysian students who have studied which personality traits (predictable characteristics and openness) predict certain characteristics of social entrepreneurial intentions (such as having a social vision or looking 
for social innovation opportunities). The practical implications of these studies suggest that policy makers and business schools want to boost the proportion of their alumni are involved, more service learning in social organizations, and it will tend to promote social entrepreneurial intentions. This research shows opportunities for future research because there is still a gap between intention and implementation which makes them motivated for this outcome to become a reality in the real world. And also need to add some variables that interact with deep beliefs or mental prototypes in forming social entrepreneurial intention.

Lacap et al, (2018) is the form of development from Hockerts, (2015) who want to research the Filipino and Indonesian university students from selected higher education institutions (HEls) using a quantitative research design and use the method of structural equation modeling - partial least square to measure the direct and indirect effects of the structural model. The result is the prior experience variable with social problems is positively and significantly related to empathy, moral obligation, social entrepreneurial self-efficacy and perceived social support as well as findings from Hockerts, (2015). This study suggests an intervention for each individual to participate in solving social problems because this can encourage people to form an increase in social entrepreneurial intention.

Kirby \& Ibrahim, (2011) use The Theoretical Framework is Ajzen's Theory of Planned Behavior. Data collection is a questionnaire survey of 183 of the 2,000 undergraduates at the British University in Egypt, drawn three faculties from the University. The findings of this study state that most students are confused about social entrepreneurship, because they do not know what to do and the actual about social entrepreneurship. Although in Egypt there are already 3 well-known social entrepreneur organizations such as Ashoka Arab World, The Schwab Foundation and Yes Egypt that strive to support and promote social enterprise in Egypt but these students do not understand it. These students are more likely to choose as wealth-creating business entrepreneurs than entrepreneurs who create social value for others.

Urban \& Kujinga, (2017), This study discusses several contextual factors from the influence of the institutional environment to individual behavior, using sample 153 students from a total population of 1,200 students in Management and Commerce at three different prominent public universities in South Africa in understanding the concept of social entrepreneurs. This study uses a quantitative data method with a cross-sectional survey design by hypothesizing the influence of different institutional profiles in social entrepreneurial intentions, by using correlation analysis and structural equation modeling. The variables used in this research are regulatory environment, normative environment, cognitive environment, Desirability, Feasibility in forming construct for social entrepreneurial intention. The results of this study show that the regulatory environment has a positive and significant result impact on feasibility and desirability. And, feasibility and desirability give a positive impact on social entrepreneurial intention.

Classification based on Research Methods. This research detected only the quantitative method and a conceptual model from the previous research. This quantitative method is used by using a survey to collect a large amount of data that affects behavior in the formation of social entrepreneurial intention.

\section{CONCLUSION}

This research was conducted using a systematic literature review to answering the research questions in the form of "What is the application of the formation of Social Entrepreneurial Intentions?". The researcher collected various articles and included inclusion to answer the criteria of the research question. The results are 6 articles found from electronic database such as the Emerald Insight, Proquest and Sage Pub. The first study of the intention of social entrepreneurship began in 2011 and began to develop the following year.

There are 2 types of research methods that were found in reviewing this study, namely in the form of quantitative data with surveys and conceptual papers. This shows that research from this field is still fairly new and appealing because researchers want to examine 
empirical research can understand the situation in shaping social entrepreneur intention. In this study there are findings of research to facilitate researchers and practitioners in the future.

Researcher suggest to using Empirical research that can be done in the future is to use theoretical framework from Theory of Planned Behavior (TPB) (Ajzen, 1991) or using modified TPB theory from Mair \& Noboa, (2006) which was adapted and tested by Hockerts (2015) and Lacap et al, (2018). The researcher saw that the research could be updated to adjust to the current situation in order to be able to resolve some of the obstacles that occurred.

Possible empirical research in the future is to use the framework of Urban and Kujinga, (2017) by looking at the variables of Desirability and Feasibility in the institutional environment. Using samples for students which are intended to provide greater heterogeneity and importance in higher education is a great potential to become candidates who promise social entrepreneurs. In the future research that can be done is to include factors such as moral judgment and empathy (Mair \& Noboa, 2006), and it can also include other factors such as environmental factors such as cultural values, and factors of observable influences such as cultural traditions, or social norms and values.

\section{REFERENCES}

1. Ajzen, I. (1991). The theory of planned behavior. Organizational Behavior and Human Decision Processes, 50, 179-211. https://doi.org/10.1016/0749-5978(91)90020-T

2. Baumol, W. J. (1993). Formal entrepreneurship theory in economics: Existence and bounds. Journal of Business Venturing, 8(3), 197-210. https://doi.org/10.1016/08839026(93)90027-3.

3. Bird, B. (1988). Implementing Entrepreneurial Ideas: The Case for Intention. Academy of Management Review, 13(3), 442-453. https://doi.org/10.5465/AMR.1988.4306970.

4. Denyer, \& Tranfield. (2003). Towards a methodology for developing evidence informed management knowledge by means of systematic review. British Journal of Management, 14, 207-222.

5. Drayton, W. (2002). The Citizen Sector. California Management Review, 44(3), 121-132.

6. Haryanti, D. M., Rahayu, S., Hati, H., Wirastuti, A., \& Susanto, K. (2016). Berani Jadi Wirausaha Sosial?, 336. Retrieved from http://dbs.com/iwovresources/pdf/indonesia/social-good/Berani-jadi-SE-24Jun2015-final.pdf.

7. Hockerts, K. (2015). Determinants of Social Entrepreneurial Intentions. Entrepreneurship: Theory and Practice, 41(1), 105-130. https://doi.org/10.1111/etap.12171.

8. Jiao, H. (2011). A conceptual model for social entrepreneurship directed toward social impact on society. Social Enterprise Journal, 7(2), 130-149. https://doi.org/10.1108/17508611111156600.

9. Kebaili, B., Al-Subyae, S. S., \& Al-Qahtani, F. (2017). Barriers of entrepreneurial intention among Qatari male students. Journal of Small Business and Enterprise Development, 24(4), 833-849. https://doi.org/10.1108/JSBED-11-2016-0186.

10. Kirby, D. A., \& Ibrahim, N. (2011). The case for (social) entrepreneurship education in Egyptian universities. Education and Training, 53(5), 403-415. https://doi.org/10.1108/00400911111147712.

11. Krueger, N. F., \& Carsrud, A. L. (1993). Entrepreneurial intentions : Applying the theory of planned behaviour. Entrepreneurship and Regional Development ', 5(October 1993), 315-330. https://doi.org/10.1080/08985629300000020.

12. Krueger, N. F., Reilly, M. D., \& Carsrud, A. L. (2000). Competing models of entrepreneurial intentions. Journal of Business Venturing, 15(5), 411-432. https://doi.org/10.1016/S0883-9026(98)00033-0.

13. Lacap, J. P. G., Mulyaningsih, H. D., \& Ramadani, V. (2018). The mediating effects of social entrepreneurial antecedents on the relationship between prior experience and social entrepreneurial intent: The case of Filipino and Indonesian university students. Journal of Science and Technology Policy Management. https://doi.org/10.1108/JSTPM- 
03-2018-0028.

14. Lent, R. W., Brown, S. D., \& Hackett, G. (1994). Toward a Unifying Social Cognitive Theory of Career and Academic Interest, Choice, and Performance. Journal Of Vocational Behaviour, 45(August 1994), 79-122. https://doi.org/10.1006/jvbe.1994.1027

15. Mair, Johanna; Robinson, J. ., \& Hockerts, K. (2006). Social entrepreneurship. https://doi.org/10.1108/14626000710773529.

16. Mair, J., \& Martí, I. (2006). Social entrepreneurship research: A source of explanation, prediction, and delight. Journal of World Business, 41(1), 36-44. https://doi.org/10.1016/j.jwb.2005.09.002.

17. Mair, J., \& Noboa, E. (2006). Social entrepreneurship: How intentions to create a social venture are formed. Social Entrepreneurship, 121-135. https://doi.org/10.1057/9780230625655.

18. Nawaser, K., Khaksar, S. M. S., Shaksian, F., \& Afshar Jahanshahi, A. (2011). Motivational and Legal Barriers of Entrepreneurship Development. International Journal of Business and Management, 6(11), 112-118. https://doi.org/10.5539/ijbm.v6n11p112.

19. Nicholls, A. (2010). The Legitimacy of Social Entrepreneurship: Reflexive Isomorphism in a Pre-Paradigmatic Field. Entrepreneurship Theory and Practice, 34(4), 611-633, 34(4), 611-633. https://doi.org/10.1057/9781137035301_11.

20. Petersen, K., Feldt, R., Mujtaba, S., \& Mattsson, M. (2008). Systematic Mapping Studies in Software Engineering. 12Th International Conference on Evaluation and Assessment in Software Engineering, 17, 10. https://doi.org/10.1142/S0218194007003112.

21. Prabhu, G. N. (1999). Career Development International Social entrepreneurial leadership. Career Development International, 4(43), 140-145. https://doi.org/10.1108/13620439910262796.

22. Seelos, C., \& Mair, J. (2005). Social entrepreneurship : Creating new business models to serve the poor. Business Horizons (2005), 48, 241-246. https://doi.org/10.1016/j.bushor.2004.11.006.

23. Thompson, E. R. (2009). Individual Entrepreneurial Intent: Construct Clarification and Development of an Internationally Reliable Metric. Entrepreneurship: Theory and Practice, 33(0), 669-695. https://doi.org/10.1111/j.1540-6520.2009.00321.x.

24. Thurik, R., \& Wennekers, S. (2004). Entrepreneurship, small business and economic growth. Journal of Small Business and Enterprise Development, 11(1), 140-149. https://doi.org/10.1108/14626000410519173.

25. Tiwari, P., Bhat, A. K., \& Tikoria, J. (2017). The role of emotional intelligence and selfefficacy on social entrepreneurial attitudes and social entrepreneurial intentions. Journal of Social Entrepreneurship, 8(2), 165-185. https://doi.org/10.1080/19420676.2017.1371628.

26. Tran, A. T. P., \& Korflesch, H. Von. (2016a). A conceptual model of social entrepreneurial intention based on the social cognitive career theory. Asia Pacific Journal of Innovation and Entrepreneurship, 10(1), 17-38. https://doi.org/10.1108/APJIE-12-2016-007.

27. Tran, A. T. P., \& Korflesch, H. Von. (2016b). A conceptual model of social entrepreneurial intention based on the social cognitive career theory. Asia Pacific Journal of Innovation and Entrepreneurship, 10(1), 17-38. https://doi.org/10.1108/APJIE-12-2016-007.

28. Tran, A. T. P., \& Von Korflesch, H. (2016). A conceptual model of social entrepreneurial intention based on the social cognitive career theory. Asia Pacific Journal of Innovation and Entrepreneurship, 10(1), 17-38. https://doi.org/10.1108/APJIE-12-2016-007.

29. Tranfield, D., Denyer, D., \& Smart, P. (2003). Towards a Methodology for Developing Evidence-Informed Management Knowledge by Means of Systematic Review *. British Journal of Managemen, 14, 207-222.

30. Urban, B., \& Kujinga, L. (2017). The institutional environment and social entrepreneurship intentions. International Journal of Entrepreneurial Behaviour and Research, 23(4), 638655. https://doi.org/10.1108/IJEBR-07-2016-0218.

31. Yunus, M. (2008). Social Entrepreneurship: New Models of Sustainable Social Change Social Business Entrepreneurs Are The Solution. (A. (Ed. . Nicholls, Ed.). Oxford: Oxford University Press. 